\title{
PENGARUH MODEL PEMBELAJARAN INKUIRI TERBIMBING TERHADAP HASIL BELAJAR SISWA PADA MATERI POKOK USAHA DAN ENERGIDI KELAS VIII SEMESTER II SMP NEGERI 1 PAGAJAHAN
}

\author{
Sinta Damawiyah danRidwan Abdullah Sani \\ Jurusan Fisika FMIPA Universitas Negeri Medan \\ sintadamawiyah@yahoo.co.id
}

\begin{abstract}
ABSTRAK
Penelitian ini bertujuan untuk mengetahui hasil belajar siswa dan bagaimana aktivitas siswa selama menggunakan model pembelajaran Inkuiri Terbimbing pada materi pokok Usaha dan Energi di kelas VIII Semester II SMP Negeri 1 Pegajahan Tahun Pelajaran 2013/2014. Jenis penelitian ini adalah penelitian quasi eksperimen dengan menggunakan design Two group pretes-postes design dengan populasi seluruh siswa kelas VIII semester II SMP Negeri 1 Pegajahan yang terdiri dari 6 kelas dengan sampel penelitian diambil 2 kelas yang ditentukan dengan teknik random sampling, yaitu kelas VIII-1 sebagai kelas eksperimen dengan menggunakan model pembelajaran Inkuiri Terbimbing dengan jumlah siswa 35 orang dan kelas VIII-2 sebagai kelas kontrol dengan menggunakan model pembelajaran konvensional dengan jumlah siswa 35 orang. Instrumen yang digunakan adalah tes hasil belajar siswa dalam bentuk pilihan berganda sebanyak 20 soal dengan 4 pilihan jawaban yang telah divalidasi. Berdasarkan analisa data diperoleh skor rata-rata pretes kelas eksperimen dan kelas kontrol yang cenderung sama sedangkan skor ratarata postes kelas ekspermen lebih tinggi dibandingkan dengan kelas kontrol. Pada waktu pembelajaran Inkuiri Terbimbing berlangsung dilakukan pengamatan terhadap aktivitas siswa dimana hasilnya dikategorikan aktif sejalan dengan peningkatan hasil belajar siswa. Hasil penelitian menunjukkan hasil belajar siswa dengan menggunakan model pembelajaran Inkuiri Terbimbing lebih tinggi dibandingkan dengan menggunakan model pembelajaran konvensional.
\end{abstract}

Kata kunci: Aktivitas, Hasil Belajar, Inkuiri Terbimbing 


\section{PENDAHULUAN}

Pendidikan merupakan kunci utama bagi bangsa yang ingin maju dan unggul dalam persaingan global. Pendidikan adalah tugas negara yang paling penting dan sangat strategis. Sumber daya manusia yang berkualitas merupakan prasyarat dasar bagi terbentuknya peradaban yang lebih baik dan sebaliknya, sumber manusia yang buruk akan menghasilkan peradaban yang buruk. Melihat realitas pendidikan di negeri ini masih banyak masalah dan jauh dari harapan bahkan cukup jauh tertinggal dari pendidikan di negara-negara lain. Oleh karena itu, pembangunan dalam bidang pendidikan sekarang ini semakin giat dilaksanakan. Berbagai carapun ditempuh untuk memperoleh pendidikan baik pendidikan secara formal maupun pendidikan secara nonformal. Berkembangnya pendidikan sudah pasti berpengaruh terhadap perkembangan ilmu pengetahuan dan teknologi. Hal ini dapat terlihat dengan semakin pesatnya perkembangan ilmu pengetahuan dan teknologi sekarang ini. Pesatnya perkembangan ilmu pengetahuan dan teknologi sekarang ini tidak dapat terlepas dari kemajuan ilmu fisika yang banyak menghasilkan temuan baru dalam bidang sains dan teknologi. Oleh karena itu, fisika ditempatkan sebagai salah satu mata pelajaran yang penting karena salah satu syarat penguasaan ilmu pengetahuan dan teknologi berhubungan dengan ilmu pengetahuan alam (IPA) yang di dalamnya termasuk fisika.

Fisika merupakan salah satu cabang sains yang diajarkan di tingkat pendidikan menengah termasuk SMP dimana fisika menekankan pada pemberian pengalaman langsung untuk mengembangkan kompetensi agar siswa menjelajahi dan memahami konsep fisika dalam kehidupan sehari-hari. Dalam belajar fisika hendaknya fakta konsep dan prinsip-prinsip fakta tidak diterima secara prosedural tanpa pemahaman. Pemahaman yang benar dan mendalam terhadap pelajaran fisika akan sangat mempengaruhi hasil belajar siswa. Namun, sampai saat ini pelajaran fisika masih dianggap sebagai pelajaran yang sulit dan menakutkan di kalangan peserta didik.

Hasil studi pendahuluan yang dilakukan peneliti di SMPN 1 Pegajahan dengan melakukan wawancara kepada guru bidang studi Fisika yaitu Nawid, S.Pd diperoleh data hasil belajar fisika pada semester ganjil yaitu nilai rata-rata 6,5 yang sudah mendapatkan nilai tambahan dari guru sedangkan kriteria ketuntasan minimal yang harus tercapai adalah 6,8 . Sehingga dapat dikatakan nilai rata-rata siswa tidak mencapai kriteria ketuntasan minimal yang diharapkan.

Hasil observasi yang dilakukan di SMPN 1 Pegajahan dengan memberikan angket kepada 34 siswa, sebanyak 21 siswa menganggap fisika itu adalah pelajaran yang sulit dan 18 siswa menganggap kegiatan belajar mengajar fisika di kelas kurang menarik dan membosankan. Padahal sebenarnya fisika merupakan ilmu yang menarik, karena semua gejala yang terjadi di alam berkaitan dengan dunia fisika. 
Tujuan belajar yang utama ialah bahwa apa yang dipelajari itu berguna di kemudian hari, yakni membantu seseorang untuk dapat belajar terus dengan cara yang lebih mudah, sehingga tercapai proses pembelajaran seumur hidup (long life education). Untuk mewujudkan hal ini, sangat dibutuhkan kerjasama antara berbagai pihak, terutama antara peserta didik atau siswa dengan pendidik atau guru. Peran guru sebagai pendidik sangat penting. Oleh karena itulah, guru dituntut dapat menerapkan berbagai metode yang efektif dan menarik bagi siswa dalam proses penyampaian materi pembelajaran.

Proses pembelajaran yang masih sering digunakan di SMPN 1 Pegajahan adalah pembelajaran konvensional yang bertujuan agar siswa mengetahui sesuatu bukan mampu melakukan sesuatu. Pembelajaran konvensional yang disampaikan guru berupa metode ceramah, tanya jawab dan pemberian tugas. Dalam hal ini, terlihat bahwa pembelajaran konvensional lebih berpusat pada guru sebagai pentransfer ilmu, sementara siswa lebih pasif sebagai penerima ilmu sehingga dengan demikian pembelajaran yang berlangsung terasa kurang menarik dan membosankan bagi siswa. Maka itu, menurut Sagala $(2009 ; 5)$ bahwa guru perlu memiliki pengetahuan tentang pendekatan dan teknikteknik mengajar yang baik dan tepat sehingga kegiatan belajar yang efektif dan efisien dapat berlangsung sesuai tujuan yang diharapkan.

Model pembelajaran yang lebih efektif digunakan untuk mengatasi permasalahan yang di alami siswa, sehingga dapat meningkatkan minat, semangat, kemampuan untuk dapat bekerja bersama teman dalam menyelesaikan suatu permasalahan, dan dengan sendirinya diharapkan dapat meningkatkan hasil belajar siswa. Adapun model pembelajaran yang perlu dikembangkan yang diharapkan dapat meningkatkan hasil belajar siswa adalah dengan menggunakan model pembelajaran Inkuiri Terbimbing.

Pembelajaran inkuiri terbimbing yaitu merupakan model pembelajaran dimana guru membimbing siswa melakukan kegiatan dengan memberi pertanyaan awal dan mengarahkan pada suatu diskusi. Guru mempunyai peran aktif dalam menentukan permasalahan dan tahap-tahap pemecahannya. Pembelajaran inkuiri terbimbing ini digunakan bagi siswa yang kurang berpengalaman belajar dengan pembelajaran inkuiri. Dengan pembelajaran ini siswa belajar lebih beorientasi pada bimbingan dan petunjuk dari guru hingga siswa dapat memahami konsep-konsep pelajaran. Pada pembelajaran ini siswa akan dihadapkan pada tugastugas yang relevan untuk diselesaikan baik melalui diskusi kelompok maupun secara individual agar mampu menyelesaikan masalah dan menarik suatu kesimpulan secara mandiri.

Pendekatan inkuiri terbimbing yaitu pendekatan inkuiri dimana guru membimbing siswa melakukan kegiatan dengan memberi pertanyaan awal dan mengarahkan pada suatu diskusi. Guru mempunyai peran aktif dalam menentukan permasalahan dan tahap-tahap pemecahannya. Pendekatan inkuiri terbimbing ini 
digunakan bagi siswa yang kurang berpengalaman belajar dengan pendekatan inkuiri. Dengan pendekatan ini siswa belajar lebih beorientasi pada bimbingan dan petunjuk dari guru hingga siswa dapat memahami konsep-konsep pelajaran. Pada pendekatan ini siswa akan dihadapkan pada tugastugas yang relevan untuk diselesaikan baik melalui diskusi kelompok maupun secara individual agar mampu menyelesaikan masalah dan menarik suatu kesimpulan secara mandiri. Model pembelajaran inkuiri terbimbing kegiatan belajar harus dikelola dengan baik oleh guru sehingga pembelajaran sudah dapat diprediksikan sejak awal. Di samping itu sebagai motivator guru berperan sebagai pemberi semangat pada siswa untuk aktif berpartisipasi. Peran ini sangat penting dalam rangka memberikan semangat dan dorongan belajar kepada siswa dalam mengembangkan keberanian siswa baik dalam mengembangkan keahlian dalam bekerja sama.

Model pembelajaran inkuiri terbimbing merupakan model inkuiri yang diorganisasikan lebih terstruktur, dimana guru mengendalikan keseluruhan proses interaksi dan menjelaskan prosedur penelitian yang harus ditempuh siswa. Pada model ini tingkat bimbingan guru cukup besar di dalam proses inkuiri yang dilakukan oleh siswa. Peran guru adalah menciptakan situasi bermasalah, menyediakan prosedur inkuiri, memberikan respon terhadap inkuiri dan menyediakan fasilitas diskusi siswa.

\section{METODE PENELITIAN}

Populasi dalam penelitian ini adalah seluruh siswa kelas VIII SMP Negeri 1 Pegajahan yang terdiri dari 6 kelas. Sampel dalam penelitian ini terdiri dari dua kelas yaitu kelas VIII-1 sebagai kelas eksperimen dan kelas VIII-2 sebagai kelas kontrol yang diambil secara cluster random sampling.

Berdasarkan penelitian yang dilakukan untuk mengetahui hasil belajar fisika siswa dilakukan dengan memberikan tes hasil belajar pada kedua kelas sebelum dan sesudah diberikan perlakuan. Desain penelitian yang digunakan desain penelitian two group pretest dan postest design.

Data yang diperoleh ditabulasikan kemudian dicari rataratanya. Sebelum dilakukan analisis data, terlebih dahulu ditentukan nilai masing-masing kelompok sampel lalu dilakukan pengolahan data dengan langkah-langkah sebagai berikut yakni; menghitung nilai rata-rata dan simpangan baku, uji normalitas menggunakan uji Lilliefors, uji homogenitas menggunakan uji $\mathrm{F}$, pengujian kesamaan rata-rata pretes menggunakan uji t dua pihak dan pengujian hipotesis menggunakan uji t pada data postes.

\section{HASIL PENELITIAN DAN PEMBAHASAN \\ Hasil Penelitian}

Penelitian ini merupakan penelitian quasi eksperimen yang melibatkan dua kelas yang diberi perlakuan berbeda. Masing-masing kelas terdiri dari 35 siswa. Adapun nilai rata-rata pretes kelas eksperimen 34,857 dan kelas kontrol 33,286 . Hasil pretes kedua kelas 
secara rinci dapat ditunjukkan pada Gambar.

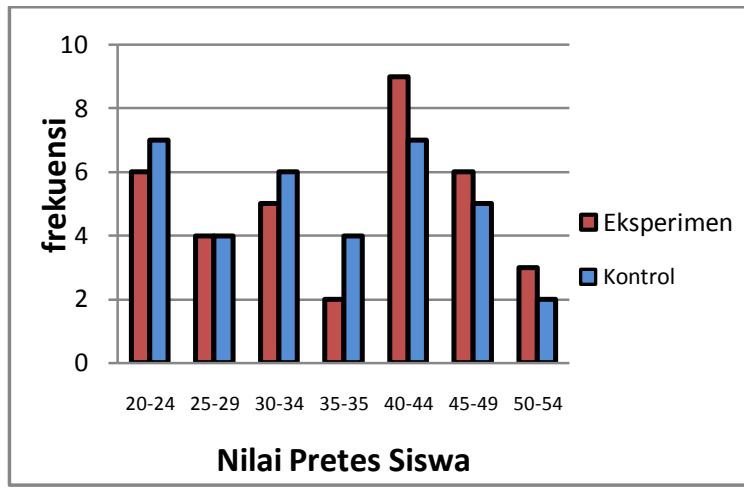

Gambar 1. Diagram batang data pretes kelas eksperimen dan kelas

Kriteria uji normalitas adalah apabila $\mathrm{L}_{\text {hitung }}<\mathrm{L}_{\text {tabel }}$ dengan $\alpha=0,05$ dapat diartikan data berdistribusi normal. Berdasarkan hasil uji normalitas dengan uji Lilliefors data pretes menunjukkan bahwa pada kelas eksperimen 0,1246<0,1498 dan kelas kontrol $0,1194<0,1498$. Sehingga dapat diartikan bahwa data hasil pretes berdistribusi normal. Uji homogenitas menggunakan uji $\mathrm{F}$ untuk data pretes diperoleh bahwa $\mathrm{F}_{\text {hitung }}<\mathrm{F}$ tabelyaitu $1,072<1,776 \quad$ dengan $a=0,10$, maka diartikan bahwa data pretes homogen. Setelah data normal dan homogen maka dapat dilakukan uji kesamaan rata-rata menggunakan uji t. Berdasarkan hasil hasil uji $t$ didapat bahwa kemampuan awal siswa sama. Maka penulis memberikan perlakuan yang berbeda di mana pada kelas eksperimen diberikan pembelajaran dengan menggunakan model pembelajaran inkuiri terbimbing sedangkan pada kelas kontrol diberikan pembelajaran langsung. Setelah itu, diberikan postes. Nilai rata-rata postes untuk kedua kelas tersebut setelah diberi perlakuan yaitu untuk kelas eksperimen sebesar 79,429sedangkan kelas kontrol sebesar 72,429. Gambar 2.

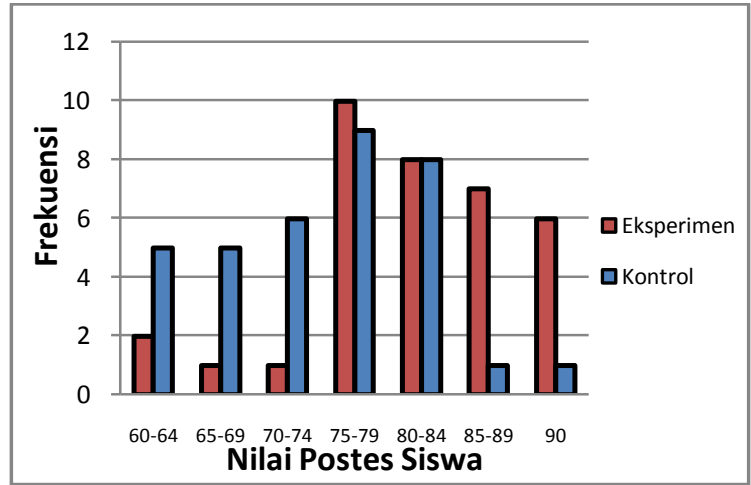

Gambar 2. Diagram batang data postes kelas eksperimen dan kelas

Hasil uji normalitas data postes diperoleh bahwa $\mathrm{L}_{\text {hitung }}<\mathrm{L}_{\text {tabel }}$ yaitu $0,1123<0,1498$ untuk kelas eksperimen dan $0,1146<0,1498$ untuk kelas kontrol. Sehingga dapat diartikan bahwa data hasil postes berdistribusi normal. Sedangkan hasil uji $\mathrm{F}$ data postes diperoleh bahwa $\quad \mathrm{F}_{\text {hitung }}<\mathrm{F}_{\text {tabel }} \quad$ yaitu $1,034<1,776$ dengan $\alpha=0,10$, maka diartikan bahwa data postes homogen.

Uji hipotesis menggunakan uji tdimaksudkan untuk mengetahui adanya pengaruh yang signifikan dari penerapan model pembelajaran inkuiri terbimbing terhadap hasil belajar siswa. Syarat dilakukannya uji t adalah data harus berdistribusi normal dan berasal dari populasi yang homogen. Setelah kedua syarat terpenuhi, maka pengujian hipotesis data postes dilakukan menggunakan uji $\mathrm{t}$ dengan $\mathrm{a}=0,05$. Berdasarkan hasil perhitungan diperoleh $t_{\text {hitung }}>t_{\text {tabel }}=3,723>1,668$ sehingga dapat disimpulkan bahwa ada pengaruh yang signifikan dari penerapan model pembelajaran 
inkuiri terbimbing terhadap hasil belajar siswa pada materi usaha dan energi.

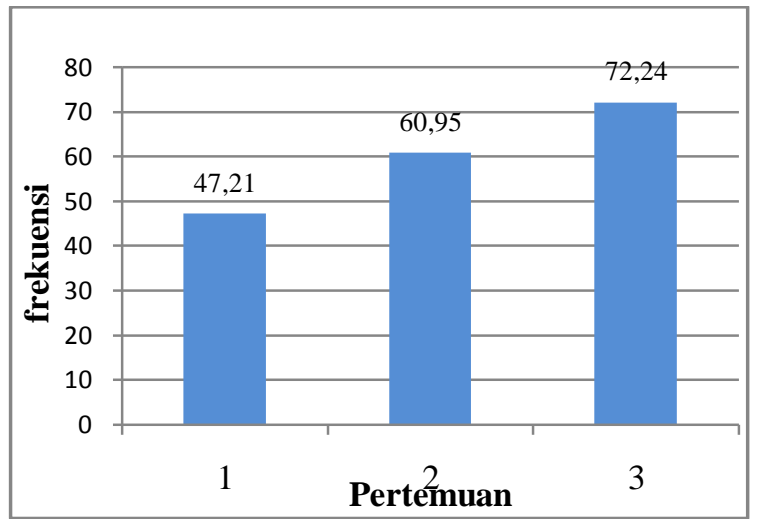

Gambar 3. Hasil observasi aktivitas siswa kelas eksperimen yang diajarkan menggunakan model pembelajaran inkuiri terbimbing mengalami peningkatan yaitu mulai dari pertemuan pertama, pertemuan kedua dan pada pertemuan ketiga.

\section{Pembahasan}

Berdasarkan data penelitian dilihat dari hasil pretes tersebut diketahui bahwa nilai rata-rata pretes siswa pada kedua kelas tersebut tidak jauh berbeda. Dimana nilai rata-rata hasil belajar siswa untuk kelas eksperimen adalah 34,857 dan standar deviasi 9,962 dengan nilai tertinggi 50 dan nilai terendah 20 sedangkan untuk kelas kontrol 33,286 dan standar deviasi 9,621 dengan nilai tertinggi 50 dan nilai terendah 20. Berdasarkan nilai rata-rata pretes tersebut terlihat bahwa hasil belajar siswa sebelum diberikan perlakuan dengan model pembelajaran yang berbeda masih tergolong sangat rendah.Hal ini dapat dipahami karena kedua kelas sampel belum menerima pembelajaran mengenai materi pokok Usaha dan Energi. Hal ini memberikan gambaran bahwa rata-rata kemampuan awal dari kedua kelas mengenai materi pokok Usaha dan Energi cenderung sama.

Sementara berdasarkan hasil postes setelah kedua kelas diberikan perlakuan dengan menggunakan model pembelajaran yang berbeda diperoleh bahwa rata-rata nilai hasil belajar siswa pada kelas eksperimen yang menggunakan model pembelajaran Inkuiri Terbimbing adalah 70,429 dengan nilai tertinggi 90 dan nilai terendah 60 serta nilai standar deviasinya adalah 7,931 sedangkan pada kelas kontrol yang menggunakan

pembelajaran konvensional diperoleh rata-rata nilai hasil belajar siswa adalah 72,429 dengan nilai tertinggi 90 dan terendah 60 serta dengan nilai standard deviasi adalah 7,800.

Setelah

dilakukan

pembelajaran dimana kelas eksperimen menggunakan model pembelajaran Inkuiri Terbimbing dan kelas kontrol menggunakan model pembelajaran konvensional, maka dilakukan uji $\mathrm{t}$ dan diperoleh $t_{\text {hitung }}>t_{\text {tabel }}=(7,723>1,668)$. Dengan demikiaan $\mathrm{H}_{0}$ ditolak dan $\mathrm{H}_{\mathrm{a}}$ diterima dengan kata lain hal ini menunjukkan bahwa ada pengaruh model pembelajaran Inkuiri Terbimbing terhadap hasil belajar siswa pada materi pokok Usaha dan Energi di kelas VIII Semester II SMP Negeri 1 Pegajahan T.P.2013/2014. Hal ini sesuai dengan hasil penelitian dari peneliti sebelumnya yaitu Vivianti Sirait (2011) dan Rosna (2010) yang menyatakan ada pengaruh model pembelajaran Inkuiri Terbimbing terhadap hasil belajar siswa.

Teori yang mendukung pembelajaran inkuiri terbimbing adalah teori konstruktivisme sosial yang dikembangkan oleh Lev 
Seomenovich Vygotsky, yang menyatakan bahwa pembentukan pengetahuan dan perkembangan kognitif terbentuk melalui internalisasi/ penguasaan proses sosial. Teori ini merupakan teori sosiogenesis, yang membahas tentang faktor primer atau kesadaran sosial dan faktor sekunder atau individu, serta pertumbuhan kemampuan. Peserta didik berpartisipasi dalam kegiatan sosial tanpa makna, kemudian terjadi internalisasi atau pengendapan dan pemaknaan atau konstruksi pengetahuan baru, swrta perubahan atau transformasi pengetahuan. Tingkat perkembangan kemampuan aktual terjadi secara mandiri dan kemampuan potensial melalui bimbingan orang dewasa. Proses konstruksi pengetahuan dilakukan secara bersama- sama dengan bantuan yang diistilahkan dengan scaffolding, misalnya dengan memberikan petunjuk, pedoman, bagan/ gambar, prosedur, atau balikan.

Penelitian ini merupakan penelitian quasi eksperiment yang melibatkan dua kelas yang diberi model pembelajaran yang berbeda yaitu kelas eksperimen diajar dengan model pembelajaran inkuiri terbimbing dan kelas kontrol dengan pembelajaran konvensional. Sebelum diberi perlakuan yang berbeda, kedua kelas terlebih dahulu diberikan pretes yang betujuan untuk mengetahui kemampuan awal siswa pada masing-masing kelas.

Berdasarkan penelitisn yang dilakukan pada kelas eksperimen dengan jumlah siswa 35 diperoleh nilai rata-rata 34,857 dan kelas kontrol yang berjumlah 35 diperoleh nilai rata-rata 33,286 . Selanjutnya setelah diberi perlakuan di kelas eksperimen dengan model pembelajaran inkuiri terbimbing, sedangkan di kelas kontrol dengan pembelajaran konvensional, dilakukan postes dan diperoleh hasil belajar yang meningkat dengan nilai rata-rata kelas eksperimen menjadi 79,429 dan kelas kontrol menjadi 72,429 .

Data hasil penelitian menunjukkan bahwa model pembelajaran inkuiri terbimbing berpangaruh terhadap hasil belajar siswa. Keberhasilan model pembelajaran latihan inkuiri didasarkan banyak hal yaitu model pembelajaran inkuiri terbimbing ini menekankan kepada proses keterlibatan siswa secara penuh untuk dapat menemukan materi yang dipelajari dan menghubungkannya dengan situasi kehidupan nyata sehingga mendorong siswa untuk dapat menerapkannya dalam kehidupan sehari-hari, dalam proses pembelajaran inkuiri terbimbing siswa tidak hanya berperan sebagai penerima pelajaran melalui penjelasan guru secara verbal, tetapi siswa berperan untuk menemukan sendiri inti dari materi pelajaran. Keterampilan siswa dalam pembelajaran dengan menggunakan model pembelajaran inkuiri terbimbing merupakan suatu proses yang bermula dari merumuskan masalah, merumuskan hipotesis, mengumpul data, menganalisis data, dan membuat kesimpulan.

Model pembelajaran inkuiri terbimbing membuat siswa lebih aktif dalam belajar, karena dengan model ini maka pengetahuan dan ketrampilan yang diperoleh oleh 
siswa diharapkan bukan hasil mengingat seperangkat fakta-fakta, tetapi hasil dari menemukan sendiri. Dengan model ini juga siswa dapat bekerja sama dan memberikan masukan-masukan pada siswa yang lain sehingga siswa yang kurang mampu menjadi lebih termotivasi untuk mempelajari materi yang kurang dimengerti.

Tingkat pemahaman yang diperoleh siswa lebih mendalam karena siswa terlibat langsung dalam proses menemukan jawaban terhadap persoalan yang ada dan langsung mempraktekkannya sehingga proses pembelajaran lebih efektif dan efesien serta siswa lebih termotivasi untuk berpikir kreatif. Model pembelajaran inkuiri terbimbing ini sangat baik untuk siswa yang memiliki rasa ingin tahu tinggi karena dengan model ini siswa menjadi lebih aktif dan terarah langsung pada intisari pembelajaran.

Model pembelajaran inkuiri terbimbing mampu membuat siswa dapat bekerja sama dan saling memberikan masukan kepada siswa yang lain sehingga siswa yang kurang mampu menjadi lebih termotivasi untuk mempelajari materi yang kurang dimengerti, serta memberikan waktu secukupnya kepada siswa untuk mengasimilasi dan mengakomodasi informasi.

Pembelajaran dengan model pembelajaran inkuiri terbimbing menunjukkan adanya pengaruh terhadap hasil belajar siswa, walaupun masih terdapat harapan yang masih kurang terpenuhi, khususnya ketika kerja kelompok berlangsung masih terdapat siswa yang kurang aktif. Model ini akan lebih baik apabila siswa terlibat aktif selama proses belajar melalui kerja kelompok, maka sebaiknya untuk mencapai hasil yang maksimal maka sebaiknya jumlah siswa di dalam kelompok cukup 2-3 orang saja. Dengan jumlah ini maka akan memungkinkan setiap siswa dalam kelompok dapat bekerja sama dengan aktif. Sementara jumlah siswa yang terlalu banyak dalam kelompok diskusi menyebabkan adanya siswa yang tidak aktif dalam pembelajaran dan hal ini akan mengganggu proses belajar dalam kelompok diskusi.

Hasil belajar yang diperoleh dalam penelitian ini hanya menggunakan alat ukur berupa tes tertulis dalam bentuk pilihan berganda. Harapan yang terkandung dalam model ini belum semuanya tercapai dengan hasil yang sangat baik, adapun faktor yang menyebabkan kondisi ini terjadi adalah disebabkan karena siswa kurang terbiasa dengan model pembelajaran inkuiri terbimbing sebelumnya, sehingga butuh waktu penyesuaian dengan siswa saat proses pembelajaran berlangsung. Oleh sebab itu hendaknya dalam proses pembelajaran sebaiknya siswa diajarkan dengan meggunakan model pembelajaran yang lebih variatif supaya siswa mampu memahami materi pelajaran fisika secara efektif dan efesien.

\section{KESIMPULAN}

Berdasarkan hasil penelitian yang diperoleh dari hasil analisa data dan pengujian hipotesis maka dapat disimpulkan, hasil belajar fisika siswa yang diberi pembelajaran dengan model pembelajaran Inkuiri Terbimbing sebelum diberikan perlakuan masih rendah dan setelah diberikan 
perlakuan rata-rata postes jadi meningkat dan tergolong tuntas sesuai nilai KKM. Dan hasil belajar fisika siswa yang diajar dengan menggunakan pembelajaran konvensional sebelum diberikan perlakuan masih rendah dan setelah diberikan perlakuan rata-rata postes siswa masih rendah dan tergolong tidak tuntas sesuai nilai KKM.Berdasarkan hasil perhitungan uji $\mathrm{t}$ diperoleh bahwa ada perbedaan akibat pengaruh menggunakan model pembalajaran Inkuiri Terbimbing terhadap hasil belajar fisikapada materi Usaha dan Energi di kelas VIII SMP Negeri 1 Pegajahan.

\section{SARAN}

Saran kepada peneliti selanjutnya yang ingin meneliti tentang model pembelajaran Inkuiri Terbimbing agar lebih baik dalam mengelola kelas sehingga suasana kelas tidak menjadi ricuh dan melengkapi alat dan bahan yang digunakan dalam proses pembelajaran sehingga proses belajar mengajar menjadi efektif. Bagi guru diharapkan menggunakan model pembelajaran Inkuiri Terbimbing sebagai salah satu alternatif dalam proses pembelajaran karena model ini adalah cara yang efektif dalam mencapai hasil belajar akademik siswa maupun sosial siswa dan secara khusus bermakna.

\section{DAFTAR PUSTAKA}

Arends, R., (2007), Learning To Teach Belajar Untuk Mengajar. Pustaka Pelajar, Yogyakarta.

Arikunto, S., (2006), Prosedur Penelitian Suatu Pendekatan Praktik, Rineka Cipta, Jakarta.
Dimayati., dan Mudjiono., (2006), Belajar dan Pembelajaran, Rineka Cipta, Jakarta.

Hamalik,O., (2011), Proses Belajar Mengajar, Bumi Aksara, Jakarta.

Istarani, (2011), 58 Model Pembelajaran Inovatif, Media Persada, Medan.

Joyce,B., Weil,M. \& Calhoun, E., (2009), Model-Model

Pengajaran, Edisi Delapan, Pustaka Belajar, Yogyakarta.

Ngalimun., (2012), Strategi dan Model Pembelajaran, Aswaja Pressindo, Yogyakarta.

Sani, R. A., (2013), Inovasi Pembelajaran, Bumi Aksara, Medan.

Sudjana, (2005), Metode Statistika, Tarsito, Bandung.

Usman, H., (2008), Pengantar Statistika, Bumi Aksara, Yogyakarta 